2008

\title{
Using RNA Interference to Determine the Role of Varisin in the Innate Immune System of the Hard Tick Dermacentor variabilis (Acari: Ixodidae).
}

\author{
Wayne L. Hynes \\ Old Dominion University, whynes@odu.edu \\ Martha M. Stokes \\ Old Dominion University \\ Shannon M. Hensley \\ Old Dominion University \\ S. Michelle Todd \\ Old Dominion University \\ Daniel E. Sonenshine \\ Old Dominion University, dsonensh@odu.edu
}

Follow this and additional works at: https://digitalcommons.odu.edu/biology_fac_pubs

Part of the Entomology Commons, and the Parasitology Commons

\section{Repository Citation}

Hynes, Wayne L.; Stokes, Martha M.; Hensley, Shannon M.; Todd, S. Michelle; and Sonenshine, Daniel E., "Using RNA Interference to Determine the Role of Varisin in the Innate Immune System of the Hard Tick Dermacentor variabilis (Acari: Ixodidae)." (2008). Biological Sciences Faculty Publications. 103.

https://digitalcommons.odu.edu/biology_fac_pubs/103 
Using RNA interference to determine the role of Varisin in the innate immune system of the hard tick Dermacentor variabilis (Acari: Ixodidae)

Wayne L. Hynes, Martha M. Stokes, Shannon M. Hensley, Michelle M. Todd, and Daniel E. Sonenshine.

Department of Biological Sciences, Old Dominion University, Norfolk, VA

Corresponding Author:

Wayne Hynes

Department of Biological Sciences

Old Dominion University

Norfolk, VA 23529-0266

USA

Ph: (757) 683-3613

FAX: (757) 683-5283

E-mail: whynes@odu.edu

Keywords: innate immunity, defensin, varisin, RNAi, antimicrobial activity. 


\section{ABSTRACT}

Defensins are an important component of the innate immune system of ticks.

These small peptides are produced by various genera of tick, and expressed in various tissues. In this study we used RNA interference to silence the expression of the defensin varisin produced by the hemocytes of the American dog tick, Dermacentor variabilis. Ticks were injected with double stranded varisin RNA prior to being put on a rabbit. After feeding, the ticks were removed and bled. Hemolymph and hemocytes were separated and screened for the presence (or absence) of both varisin transcript and peptide. Varisin peptide was below detectable levels and the transcript showed a greater than $99 \%$ knockdown. The antimicrobial activity of the hemolymph plasma was reduced 2 to 4 fold compared to that of control injected ticks indicating varisin accounts for a large portion of the antimicrobial activity of the hemolymph. 


\section{INTRODUCTION}

Ticks are obligate blood-feeding ectoparasites that have the ability to transmit a wide variety of disease causing microbes. In fact, they have the ability to transmit more disease causing microbes than any other blood feeding arthropod, including mosquitoes, although mosquitoes cause more human illness than those caused by tick-borne agents. The hard tick Dermacentor variabilis (American dog tick) can be found throughout the southeastern USA, and up the east coast to Nova Scotia (Brown 2005). This hard tick is a vector of the pathogens responsible for Rocky Mountain Spotted Fever (RMSF), human monocytotrophic ehrlichiosis (HME), tularemia, and is capable of causing tick paralysis. However, ticks are more than 'syringes-on-legs'. Although lacking the highly developed, adaptive immune response found in vertebrates, ticks have an efficient innate immune response. The innate immune system consists of both cellular and soluble components (Gillespie et al. 1997; Schmid-Hempel 2005) that are effective in eliminating many microbes. The cellular responses include phagocytosis, nodulation, and encapsulation (Eggenberger et al. 1990; Inoue et al. 2001; Ceraul et al. 2002; Sonenshine and Hynes 2008). The soluble aspects of the innate immune response include production of antimicrobial peptides including defensins (Bulet et al. 2003; Sonenshine and Hynes 2008).

Invertebrates produce many different types of antimicrobial molecules when challenged by microbes or parasites (Cociancich et al. 1994; Bulet et al. 2003; Tsuji et al. 2007; Sonenshine and Hynes 2008). Among the most conserved of 
these molecules are the defensins. Defensins are small cationic peptides, generally $34-61$ amino acids for the mature peptide (3-6kDa), produced by organisms from plants to invertebrates to the most complex mammals (Bulet et al. 2003; Sonenshine and Hynes 2008). Insect defensins generally have six cysteine residues that form three disulfide bridges with linkages being Cys1Cys4, Cys2-Cys5, and Cys3-Cys6 (Bulet et al. 1999; Bulet et al. 2003); the exception being drosomycin, produced by Drosophilia melanogaster which has four disulfide bonds and antifungal activity (Michaut et al. 1996; Bulet et al. 2003). To date more than 20 defensins have been identified from 11 species of tick (Sonenshine and Hynes 2008). Defensins are produced as a prepro form, which is cleaved to release the mature peptide at a highly conserved RVRR site (Sonenshine and Hynes 2008). Some species of tick have multiple isoforms of defensin, with Omithodoros moubata having four isoforms (Nakajima et al. 2001; Nakajima et al. 2002) and I. ricinus having two isoforms (Rudenko et al. 2007), while others appear to have only one form (Hynes et al. 2005; Todd et al. 2007). The first defensin recognized from a hard tick was varisin, isolated from the hemolymph of American dog tick, Dermacentor variabilis (Johns et al. 2001). The transcript sequence of varisin was determined following RT-PCR from RNA isolated from hemocytes (Ceraul et al. 2003). It appears that varisin is produced in the hemocytes and released into the hemolymph following microbial challenge. Although transcript has been detected in various tissues (Ceraul 2005;

Sonenshine et al. 2005; Ceraul et al. 2007) the peptide has only been detected in the hemolymph/hemocytes. Recently a second defensin has been reported from 
D. variabilis which had less than $50 \%$ similarity to varisin (Ceraul et al. 2007). In order to understand the role of varisin in the innate immune system of $D$. variabilis, the expression of the varisin gene was silenced using RNA interference (RNAi). RNAi has been used to study gene function in ticks due to the lack of other means of genetic manipulation (de la Fuente et al. 2005; de la Fuente et al. 2007). In this study we show that RNAi can be used to silence the gene for varisin and that silencing results in a decreased level of antimicrobial activity of tick hemolymph.

\section{MATERIALS AND METHODS}

Ticks, Injection, and Bleeding

D. variabilis were from a colony maintained at Old Dominion University as previously described (Johns et al. 1998; Johns et al. 2001). All use of animals in this research was done in accordance with protocols approved by the Old Dominion University Institutional Animal Use and Care Committee. Unfed virgin female ticks were injected with $1-5 \mu$ l of double stranded RNA (dsRNA), or Shens solution for the controls, using a $30 \mathrm{~g} \times 1 / 2$ " hypodermic needle attached to a $10 \mu \mathrm{l}$ Hamilton syringe. Injection was via the foramen between the capitulum and anterior end of the scutum. After injection, the needle was held in the tick's body for $30 \mathrm{~min}$ to prevent leakage of the injected material. Subsequently, the ticks were confined within plastic capsules attached to New Zealand white Rabbits 
(Oryctolagus cuniculus). After feeding for 5 days the ticks were forcibly removed from the rabbit and hemolymph was collected by severing the forelegs at the coxal-trochanteral joint and applying gentle pressure to the body. The clear amber-colored liquid expressed was collected in a glass micropipette and put into either $20 \mu$ l Shen's saline solution (Oliver et al. 1974) or 100 1 INA later (Applied Biosystems, Foster City, CA) depending on the assay; Shens for protein and antimicrobial assays, RNA later for RT-PCR reactions. Approximately the same number of ticks were used for both control and test injections.

Previous results have suggested storage of varisin in the hemocytes which is released on challenge (Ceraul et al. 2003). Stored varisin should be released on injection of the dsRNA. To show no new varisin was made and stored after injection of the dsRNA, some ticks were pin-pricked (wounded) and allowed to sit for $1 \mathrm{~h}$ prior to bleeding.

Double stranded RNA production

Double-stranded RNA was prepared from a PCR product containing the entire 624bp cDNA fragment of varisin derived from $D$. variabilis hemocytes using the MEGAscript RNAi kit (Applied Biosystems). The gene was first amplified from a plasmid (Ceraul et al. 2003) using the primers DEFT75: $5^{\prime}$ -

TAATACGACTCACTATAGGGTACTATGCGCGGACTTTGCATCTGC and DEFT733: $5^{\prime-}$

TAATACGACTCACTATAGGGTACTTACGTCGACAAAGCGCTTCGG which 
contain the $\pi 7$ promoter for in vitro transcription (shown in italics). Amplification was carried out using the following cycle parameters: $94^{\circ} \mathrm{C}$ for 2 minutes, followed by 35 cycles of $94^{\circ} \mathrm{C}$ for $30 \mathrm{~s}$ and $68^{\circ} \mathrm{C}$ for $1 \mathrm{~min} ; 68^{\circ} \mathrm{C}$ for $7 \mathrm{~min}$ completed the run. The PCR fragment was then used in the transcription reaction as described by the manufacturer. After transcription, the reaction was treated to remove DNA and single stranded RNA, then purified, and ethanol precipitated. The dsRNA was then resuspended in Shen's solution for injection into ticks. Control ticks were injected with the same volume of Shen's solution. Ticks were injected with $10^{11}-10^{12}$ molecules of dsRNA as described above.

\section{Quantitative RT-PCR}

Using the "illustra QuickPrep Micro mRNA purification kit" (GE Healthcare, NJ) the mRNA was isolated from hemolymph collected in RNA-later. The isolated mRNA was then treated with Turbo DNA-free (Applied Biosystems) to remove any residual DNA; this step was repeated if necessary. Reverse transcription reactions were carried out using the ImProm-II Reverse Transcription System in the presence of RNasin according to the manufacturers instructions (Promega Corp, Madison, WI) using either Oligo(dT) or random hexamer primers. The synthesized CDNA was then used in real-time PCR reactions. Controls, in which reverse transcriptase was not added, were set up for each reaction to ensure no DNA contamination. 
Real-time PCR

Real-time PCR was carried out using the $\mathrm{RT}^{2}$ SYBR Green qPCR Master Mix (SuperArray Bioscience Corporation, Frederick, MD) on a Cepheid Smartcycler (Cepheid, Sunnyvale, CA). Control real-time reactions were set up monitoring actin expression using $0.2 \mu \mathrm{M}$ final concentration of actinF ( $5^{\prime}$ -

GTACGCCAACACCGTTCTC-3') and actinR (5'ATCTTGATCTTCATGGTGGAA-3') primers. Reactions for the detection of varisin were $0.2 \mu \mathrm{M}$ defF (5'-CTTCGGATGCCCACTGAA-3') and defR (5'AGCAGGTGCAGGTCT-3'). The cDNA template $(1 \mu \mathrm{l})$ was added last to the $25 \mu \mathrm{l}$ reaction. All reactions were run on the same program: $95^{\circ} \mathrm{C}$ for 60 s then 40 cycles of $95^{\circ} \mathrm{C}$ for $15 \mathrm{~s}, 60^{\circ} \mathrm{C}$ for $60 \mathrm{~s}$, and followed by a melt curve. $\mathrm{C}_{\mathrm{T}}$ values were determined and used either in the comparative $C_{T}$ method $\left(\Delta \Delta C_{T}\right)$ for relative quantification, or to determine the actual number of molecules based on a standard curve derived from adding known amounts of plasmid DNA to a set of real-time reactions. Controls without reverse transcriptase and without template were set up with each set of samples.

Protein gels

Hemolymph collected in Shen's solution was used to check for the presence or absence of the varisin band in both hemolymph plasma and hemocyte lysate. Hemocytes were collected from the hemolymph by centrifugation at $1000 \times \mathrm{g}$ for 20 minutes at $4^{\circ} \mathrm{C}$. The pellet was resuspended in $10 \mu l$ water and frozen until 
needed. Cells were thawed and $4 \mu$ l of the hemocytes were mixed with loading buffer and reducing agent, then heated at $70^{\circ} \mathrm{C}$ for $10 \mathrm{~min}$ before loading on a 4$12 \%$ NuPAGE Tris-Bis SDS gel (Invitrogen) with See Blue molecular weight marker (Invitrogen). After electrophoresis at 200V for 35min, the gel was silver stained using the Silver Express staining kit (Invitrogen). A western blot analysis of a similarly run gel was carried out as previously described (Ceraul et al. 2003) except that the primary antibody (anti-varisin) diluted 1:50.

\section{Antimicrobial assay}

Antimicrobial activity of hemolymph plasma was assessed using a well diffusion assay. Samples $(10 \mu l)$ to be tested were pipetted into $4 \mathrm{~mm}$ diameter wells cut into a tryptic soy agar plates, then allowed to dry, exposed to chloroform vapors for 20 minutes, and aired. An overnight culture of Micrococcus luteus was seeded onto the su face of the plate using a sterile swab, and the plate incubated at $37^{\circ} \mathrm{C}$ overnight. Zones of inhibition were seen as areas of no growth around the wells. Two fold dilution series were carried out using $0.9 \%$ saline as the diluent. The titer (arbitrary units, AU) was determined as the last dilution to show a zone of growth inhibition.

\section{RESULTS}




\section{Antimicrobial assay}

Screening of undiluted hemolymph plasma for antimicrobial activity against $M$. luteus indicated less activity in the dsRNA treated tick hemolymph, than in the ticks injected with Shen's solution (Figure 1). When the hemolymph was two-fold serially diluted, titers for the control (Shens injected) were 2-4 times higher than the test (dsRNA injected) sample. Control titers were 8-16 AU whereas the dsRNA injected tick hemolymph was 4 AU.

Loss of varisin peptide in hemolymph plasma and cells Cell lysate and hemolymph plasma were visualized on a polyacrylamide gel, stained for protein. As is shown in Figure 2a, the varisin peptide band is missing or very faint from the hemolymph of those ticks treated with dsRNA, while those treated with buffer still show the presence of a varisin-sized band. The same effect was seen with hemocyte extracts, in that the varisin band is present in the hemocytes of control ticks but not those injected with the dsRNA construct. Western blot analysis using the anti-varisin antibody confirmed the loss of the defensin in both hemolymph plasma (Figure $2 b$ ) and hemocytes (not shown). The presence of multiple bands in the western blot is most likely due to the nonspecific binding of antibodies to tick proteins as previously described (Ceraul et al. 2003). 
To detect release of the varisin peptide following a wounding response, ticks were also wounded $1 \mathrm{~h}$ prior to bleeding and collecting the hemolymph. Figure 2 shows that the wounding does not result in release of varisin from dsRNA treated ticks. No difference was seen in the presence or absence of the varisin band between non-wounded and wounded ticks.

\section{Real-time PCR assays}

Real-time PCR was used to determine the degree to which varisin transcription was silenced in treated ticks. Representative results are shown in Figure 3. Treatment with dsRNA results in a decrease in the amount of varisin transcript as seen by the number of cycles required for the transcript to be detected. Figure 3 shows control and treated samples amplified using the varisin primers. The insert shows the graphs of control and treated reactions with the actin amplification; this ensures equal amounts of template were added to the reaction.

The effect of treatment can easily be seen in this graph but to gain insight into how much the gene is silenced in our samples we determined the amount of transcript remaining using both the relative quantification and standard curve methodologies. A standard curve was prepared in which the $C_{T}$ was plotted against the number of molecules present; we used ten-fold dilutions from $10^{9}$ through $10^{3}$ copies of the varisin gene. Using the standard curve to determine the number of molecules of varisin, we found that injection of dsRNA for varisin resulted in a 99-99.5\% knockdown. Using the $\Delta \Delta C_{T}$ method for relative 
quantification treatment with dsRNA the knockdown was as high as $99.9 \%$. These results show that injection of varisin dsRNA effectively silences the expression of the varisin gene.

\section{DISCUSSION}

RNA interference is an effective way of examining gene function in ticks, and has been used to target a number of different genes (de la Fuente et al. 2007). We can now add to this list varisin, which we believe to be the major defensin in tick hemolymph. Inactivation of varisin results in a 2-4 fold reduction in the antimicrobial activity of tick hemolymph as determined by our plate assays. However, it does not account for all the inhibitory activity since hemolymph plasma from the treated ticks were still able to inhibit the growth of Micrococcus luteus. What accounts for the other antimicrobial activity seen in the hemolymph? Perhaps the most likely candidate is lysozyme, which is known to be expressed by $D$. variabilis hemocytes (Simser et al. 2004; Ceraul et al. 2007) and possibly released into the hemolymph plasma fraction. We have previously shown that a lysozyme is able to enhance the antimicrobial activity of varisin (Johns et al. 2001). Whether authentic tick lysozyme functions with varisin in the same manner as the egg white lysozyme remains to be determined. What would happen to the antimicrobial titer of tick hemolymph if we silenced lysozyme expression as well as varisin? RNAi studies into this aspect are currently underway in our laboratory. 
There are a number of other possible antimicrobial molecules that are present in tick hemolymph (Sonenshine and Hynes 2008) that could result in the effects seen here, i.e. only partial loss of the ability to inhibit bacterial growth. One possible peptide that could be responsible for some activity would be the second defensin reported from $D$. variabilis, defensin-2 (Ceraul et al. 2007). However this is an unlikely player in the antimicrobial activity of hemolymph since it is expressed by the midgut and not expressed by hemocytes.

Defensins have been implicated as major players in the innate immune response of ticks. We have shown that RNAi can be used to target and silence varisin expression in hemocytes and therefore in hemolymph. We have previously reported that varisin was most likely produced and stored in the hemocytes (Ceraul et al. 2003) then released into the hemolymph on wounding or following microbial challenge. New defensin would then be made at a later time (Ceraul 2005). In this study, the initial challenge would be the injection of dsRNA into the hemocoel, resulting in release of the stored defensin. Varisin released at the time of dsRNA injection would be expected to have been lost from the tick within $24 \mathrm{~h}$ (Johns 2003). Since we do not detect any defensin in the hemocytes or released into the hemolymph, even after another wounding (Figure 2), it appears that RNAi effectively prevents synthesis of new varisin. What effect this has on the tick, beyond any role in the innate immune response, is unknown since defensin has been suggested to have an alternative function in mosquito 
immunity (Bartholomay et al. 2004). What, if any, additional or alternative roles varisin has in tick immunity requires further investigation, as is the actual in vivo effect of varisin silencing.

\section{ACKNOWLEDGEMENTS}

We thank the National Research Fund for Tick-Borne Diseases and the National Science Foundation (IBN 0212901) for the support of this research.

\section{REFERENCES:}

Bartholomay, L. C., J. F. Fuchs, L. L. Cheng, E. T. Beck, J. Vizioli, C. Lowenberger and B. M. Christensen (2004) Reassessing the role of defensin in the innate immune response of the mosquito, Aedes aegypti. Insect Mol Biol 13: 125-132.

Brown, R. N., R.S. Lane, and D.T. Dennis (2005) Geographic Distributions of Tick-Borne Diseases and Their Vectors. In: Goodman, J. L., D.T. Dennis, and D.E. Sonenshine (eds). Tick-borne Diseases of Humans: 363-391. ASM Press, Washington D.C.

Bulet, P., M. Charlet and C. Hetru (2003) Antimicrobial peptides in insect immunity. In: Ezekowitz, R. A. B. and Hoffmann, J. A. (eds). Innate Immunity: 89-107. Humana Press Inc, Totowa.

Bulet, P., C. Hetru, J. L. Dimarcq and D. Hoffmann (1999) Antimicrobial peptides in insects; structure and function. Dev Comp Immunol 23: 329-344.

Ceraul, S. M. (2005) PhD Dissertation. Department of Biological Sciences, Old Dominion University, Norfolk

Ceraul, S. M., S. M. Dreher-Lesnick, J. J. Gillespie, M. S. Rahman and A. F. Azad (2007) New tick defensin isoform and antimicrobial gene expression in response to Rickettsia montanensis challenge. Infect Immun 75: 1973-1983.

Ceraul, S. M., D. E. Sonenshine and W. L. Hynes (2002) Resistance of the tick Dermacentor variabilis (Acari: Ixodidae) following challenge with the bacterium 
Escherichia coli (Enterobacteriales: Enterobacteriaceae). J Med Entomol 39: 376-383.

Ceraul, S. M., D. E. Sonenshine, R. E. Ratzlaff and W. L. Hynes (2003) An arthropod defensin expressed by the hemocytes of the American dog tick, Dermacentor variabilis (Acari: Ixodidae). Insect Biochem Mol Biol 33: 1099-1103.

Cociancich, S., P. Bulet, C. Hetru and J. A. Hoffmann (1994) The Inducible Antibacterial Peptides of Insects. Parasitol. Today 10: 132-138.

de la Fuente, J., C. Almazan, E. F. Blouin, V. Naranjo and K. M. Kocan (2005) RNA interference screening in ticks for identification of protective antigens. Parasitol. Res. 96: 137-141.

de la Fuente, J., K. M. Kocan, C. Almazan and E. F. Blouin (2007) RNA interference for the study and genetic manipulation of ticks. Trends Parasitol 23: 427-433.

Eggenberger, L. R., W. J. Lamorreaux and L. B. Coons (1990) Hemocytic encapsulation of implants in the tick, Dermacentor variabilis. Exp. Appl. Acarol. 9: 279-287.

Gillespie, J. P., M. R. Kanost and T. Trenczek (1997) Biological mediators of insect immunity. Annu Rev Entomol 42: 611-643.

Hynes, W. L., S. M. Ceraul, S. M. Todd, K. C. Seguin and D. E. Sonenshine (2005) A defensin-like gene expressed in the black-legged tick, Ixodes scapularis. Med Vet Entomol 19: 339-344.

Inoue, N., K. Hanada, N. Tsuji, I. Igarashi, H. Nagasawa, T. Mikami and K. Fujisaki (2001) Characterization of phagocytic hemocytes in Omithodoros moubata (Acari: Ixodidae). J Med Entomol 38: 514-519.

Johns, R. (2003) Ph.D. Dissertation. Department of Biological Sciences, Old Dominion University, Norfolk, VA, USA.

Johns, R., J. Ohnishi, A. Broadwater, D. E. Sonenshine, A. M. De Silva and W. L. Hynes (2001) Contrasts in tick innate immune responses to Borrelia burgdorferi challenge: immunotolerance in Ixodes scapularis versus immunocompetence in Dermacentor variabilis (Acari: Ixodidae). J Med Entomol 38: 99-107.

Johns, R., D. E. Sonenshine and W. L. Hynes (1998) Control of bacterial infections in the hard tick Dermacentor variabilis (Acari: Ixodidae): evidence for the existence of antimicrobial proteins in tick hemolymph. J Med Entomol 35: 458-464. 
Johns, R., D. E. Sonenshine and W. L. Hynes (2001) Identification of a defensin from the hemolymph of the American dog tick, Dermacentor variabilis. Insect Biochem Mol Biol 31: 857-865.

Michaut, L., P. Fehlbaum, M. Moniatte, A. Van Dorsselaer, J. M. Reichhart and P. Bulet (1996) Determination of the disulfide array of the first inducible antifungal peptide from insects: drosomycin from Drosophila melanogaster. FEBS Lett 395: 6-10.

Nakajima, Y., A. van der Goes van Naters-Yasui, D. Taylor and M. Yamakawa (2001) Two isoforms of a member of the arthropod defensin family from the soft tick, Omithodoros moubata (Acari: Argasidae). Insect Biochem Mol Biol 31: 747751.

Nakajima, Y., A. van der Goes van Naters-Yasui, D. Taylor and M. Yamakawa (2002) Antibacterial peptide defensin is involved in midgut immunity of the soft tick, Omithodoros moubata. Insect Mol Biol 11: 611-618.

Oliver, J. H. J., P. R. Wilkenson and G. M. Kohls (1974) Observations on hybridization on three species of North American Dermacentor ticks. J. Parasitol. 58: $375-380$.

Rudenko, N., M. Golovchenko and L. Grubhoffer (2007) Gene organization of a novel defensin of Ixodes ricinus: first annotation of an intron/exon structure in a hard tick defensin gene and first evidence of the occurrence of two isoforms of one member of the arthropod defensin family. Insect Mol Biol 16: 501-507.

Schmid-Hempel, P. (2005) 'Evolutionary ecology of insect immune defenses. Annu Rev Entomol 50: 529-551.

Simser, J. A., K. R. Macaluso, A. Mulenga and A. F. Azad (2004) Immuneresponsive lysozymes from hemocytes of the American dog tick, Demacentor variabilis and an embryonic cell line of the Rocky Mountain wood tick, $D$. andersoni. Insect Biochem Mol Biol 34: 1235-1246.

Sonenshine, D. E. and W. L. Hynes (2008) Molecular characterization and related aspects of the innate immune response in ticks. Frontiers in Bioscience In press.

Sonenshine, D. E., W. L. Hynes, S. M. Ceraul, R. Mitchell and T. Benzine (2005) Host blood proteins and peptides in the midgut of the tick Dermacentor variabilis contribute to bacterial control. Exp Appl Acarol 36: 207-223.

Todd, S. M., D. E. Sonenshine and W. L. Hynes (2007) Tissue and life-stage distribution of a defensin gene in the Lone Star tick, Amblyomma americanum. Med Vet Entomol 21: 141-147. 
Tsuji, N., B. Battsetseg, D. Boldbaatar, T. Miyoshi, X. Xuan, J. H. Oliver, Jr. and K. Fujisaki (2007) Babesial vector tick defensin against Babesia sp. parasites. Infect Immun 75: 3633-3640. 
Figure legends:

Figure 1. Antimicrobial activity of hemolymph against Micrococcus luteus from control (a) and treated (b) ticks. The same volume of hemolymph was added to each well. The lower well was buffer control. Hemolymph used in this assay was from 2 separate injections of varisin dsRNA

Figure 2. PAGE (a) and Western blot (b) showing inhibition of defensin production by vsn dsRNA. MW is molecular weight markers. Lanes 1 and 2 are those injected with Shen's, lanes 3 and 4 are ticks injected with dsRNA. Lanes 1 and 3 are samples in which the tick was bled after removal from the rabbit, 2 and 4 are samples obtained $1 \mathrm{~h}$ after the ticks were wounded. The arrow indicates the varisin band.

Figure 3. Real time PCR results following amplification of cDNA derived from control and treated (dsRNA) tick hemocytes. The insert shows the same graph with amplifcation for actin from the same samples as used for varisin amplification. 


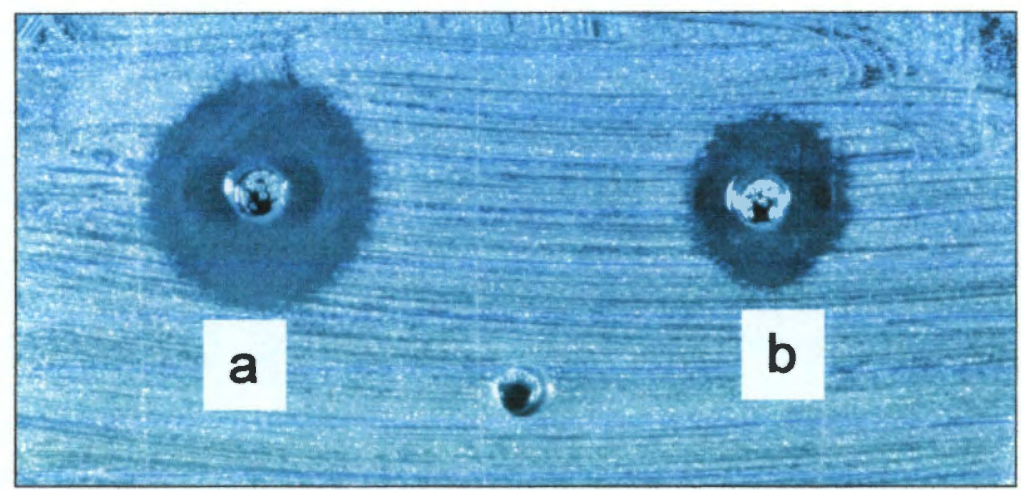

Figure 1. 


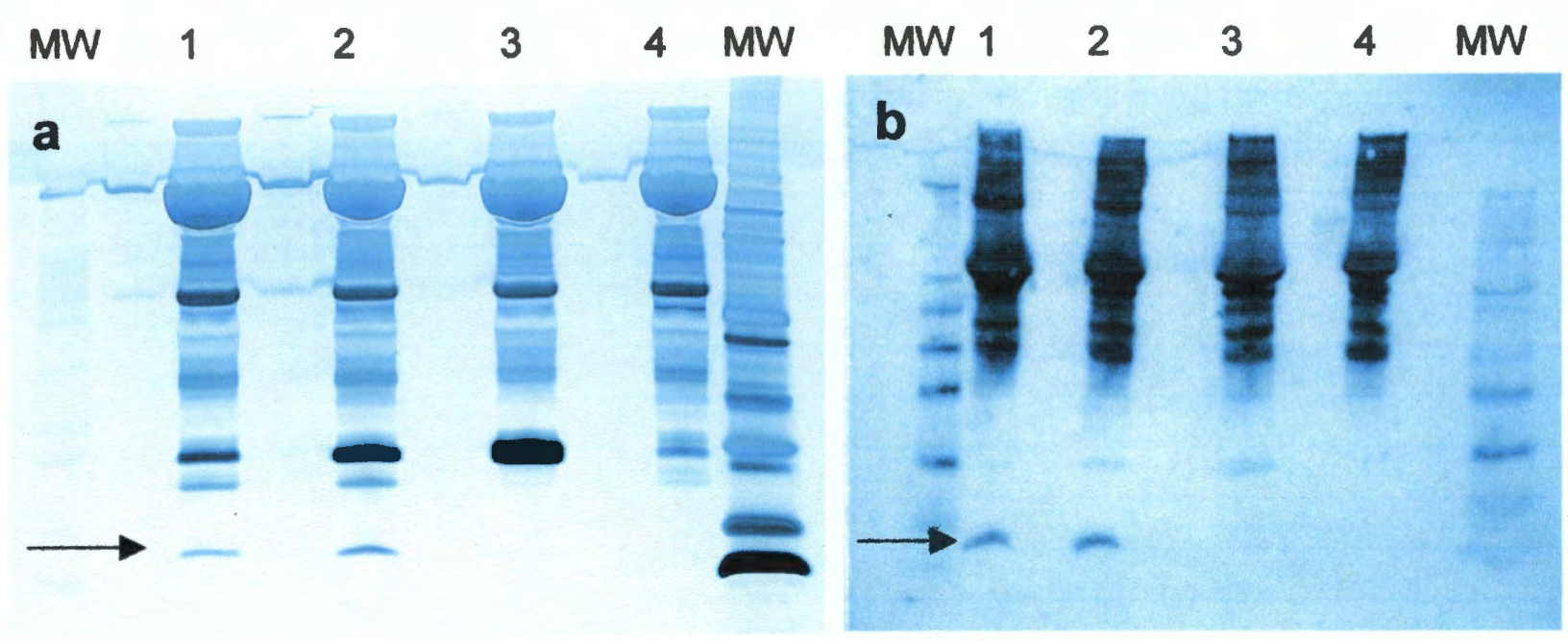

Figure 2. 


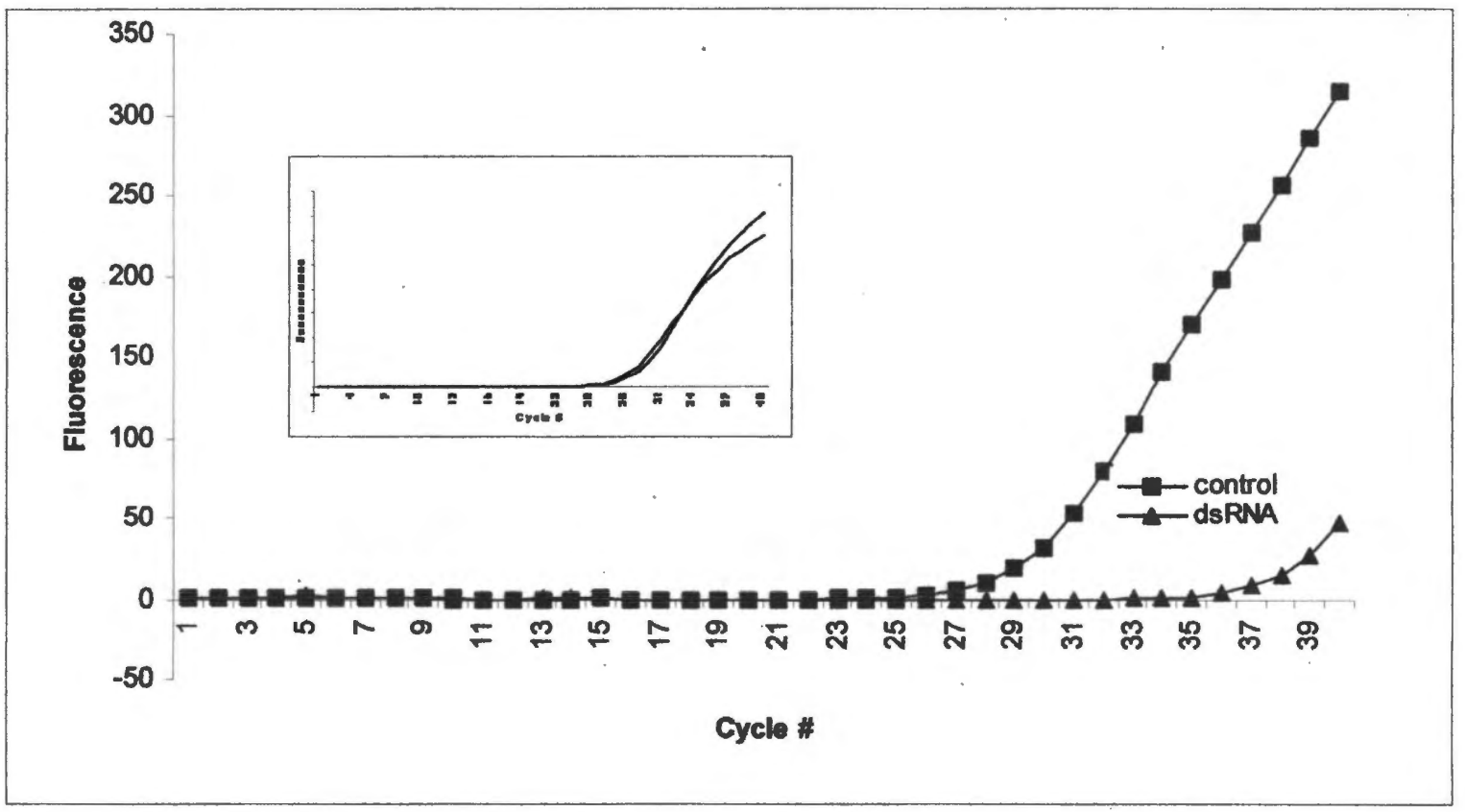

Figure 3. 